\title{
Search of phyto-toxicity microorganisms for weeds
}

Didovich S.V., Pas' A.N., Alekseenko O.P.

FSBSI "Research Institute of Agriculture of Crimea", Simferopol, Crimea E-mail: sv-alex.68@mail.ru

Key message. Phyto-toxic strains for Ambrosia artemisiifolia, Amaranthus retroflexus, Cirsium arvense have been identified. The intensity of the lesion exceeded the control by 5-70 times ( $p<$ [0.0001-0.007]), depending on the strain and the location of the stomata.

Keywords: phyto-toxic active strains, Cirsium arvense (L.) Scop., Amaranthus retrofleksus L., Ambrosia artemisiifolia L. The problem of weed control in agrocenoses of Russia is relevant due to the loss of yield crops in the range of $15-18 \%$, and for row crops $50 \%$ or more. Microbial preparations are safe for ecosystems. They are an alternative to chemical herbicides. Biotechnologies for growing agricultural crops must be developed. This is according with the Federal Law of the Russian Federation No. 280-FL "On organic products" from January 1, 2020.

The purpose of our work is to search of phyto-toxic active microorganisms for weeds of agrocenoses such as Cirsium arvense (L.) Scop., Amaranthus retroflexus L., Ambrosia artemisiifolia L. and further use in bio-technology of plant protection.

Strains of microorganisms from the Crimean Collection of Microorganisms of FSBSI "Research Institute of Agriculture of Crimea" (http://www.ckp-rf.ru/usu/507484/), the Algal Collection of Soil Science Institute (ACSSI) of the Institute of Physicochemical and Biological Problems of Soil Science RAS (http://acssi.org/index.php/catalogue), the Collection of FSBSI "All-Russian Research Institute for Plant Protection" of "State Collection of Microorganisms Pathogenic to Plants and their Pests" (http://www.ckp-rf.ru/usu/200616/ ) and new strains, isolated in 2018-2019 were used in the study. The phytotoxicity of 22 strains of heterotrophic and phototrophic microorganisms and their preparative forms were evaluated in a laboratory experiment with use a bio-sample on the leaves of weeds Cirsium arvense (L.) Scop., Amaranthus retroflexus L., Ambrosia artemisiifolia L. Treatment was performed with a suspension of microorganisms in a dose of $10^{5}$ cells or $10 \mathrm{ml}$ of culture filtrate $/ \mathrm{cm}^{2}$ of leaf disk or die-cutting, taking into account the location of stomata. Experiments were repeated four times. The intensity of the lesion was determined visually with use a five-point system. Phyto-toxic active strain Stagonosporopsis heliopsidis 32.8 was a control on ragweed, water was a control on other weeds.

Five phytotoxic strains for Ambrosia artemisiifolia L., two strains for Amaranthus retroflexus L. and three strains for Cirsium arvense (L.) Scop. were identified as a result of research with use the conservative a posteriori Duncan criterion. According to the intensity of the lesion, these strains significantly exceeded the control by 5-70 times ( $p<$ [0.0001-0.007]), depending on the preparation form and location of the stomata.

The reported study was funded by the State Assignment of Russian Academy of Sciences No. 0834-2019-0003 and RFBR according to the research project No. 18-016-00184 A.

\section{Поиск фитотоксичных микроорганизмов для сорных растений}

Дидович С.В., Пась А.Н., Алексеенко О.П.

ФГБУН «Научно-исследовательский институт сельского хозяйства Крыма», Симферополь, Крым

\begin{abstract}
Аннотация. Выявлены фитотоксичные итаммы для Ambrosia artemisiifolia, Amaranthus retrofleksus, Cirsium arvense. Интенсивность поражения превышала контроль в 5-70 раз (p < [0,0001-0,007]) в зависимости от штамма и расположения устьиц.
\end{abstract}

Ключевые слова: фитотоксически активный штамм, Cirsium arvense (L.) Scop., Amaranthus retrofleksus L., Ambrosia artemisiifolia $L$.

Проблема борьбы с сорной растительностью в агроценозах России актуальна из-за потерь урожая зерновых культур в пределах 15-18\%, а для пропашных культур 50\% и более. Необходимо разрабатывать альтернативные химическим гербицидам безопасные для экосистем микробные препараты и биотехнологии выращивания агрокультур, что согласуется с принятием Федерального закона РФ №280-Ф3 «Об органической продукции», вступившим в силу с 1 января 2020 года.

Целью нашей работы стало проведение поиска фитотоксически активных микроорганизмов для сорных растений агроценозов (Cirsium arvense (L.) Scop., Amaranthus retrofleksus L., Ambrosia artemisiifolia L.) и дальнейшего использования в биотехнологии защиты растений.

В исследовании использовали штаммы микроорганизмов из Крымской коллекции микроорганизмов ФГБУН «НИИСХ Крыма» (http://www.ckp-rf.ru/usu/507484/), Альгологической коллекции ИФХиБПП РАН (http://acssi.org), коллекции ФГБНУ «Всероссийский научно-исследовательский институт защиты растений» (http://www.ckp-rf.ru/usu/200616/) и новые штаммы, выделенные в 2018-2019 гг. Фитотоксичность 22 штаммов гетеротрофных и фототрофных микроорганизмов и их препаративных форм оценивали в лабораторном опыте методом биопробы на листьях сорных растений Cirsium arvense (L.) Scop., Amaranthus retrofleksus L., Ambrosia artemisiifolia L. Обработку проводили суспензией микроорганизмов в дозе $10^{5}$ клеток либо 10 мкл культурального фильтрата) / см² листового диска или высечки с учетом расположения устьиц в четырех повторениях. Интенсивность поражения определяли визуально по пятибалльной системе. Контролем на амброзии был фитотоксически активный штамм Stagonosporopsis heliopsidis 32.8, на других сорных растениях - вода.

В результате исследования при статистической оценке с помощью консервативного апостериорного критерия Дункана выявлены пять фитотоксичных штаммов для Ambrosia artemisiifolia L., два штамма для Amaranthus retrofleksus L. и три штамма для Cirsium arvense (L.) Scop., которые по интенсивности поражения достоверно превышали контроль в 5-70 раз (р $<[0,0001-0,007])$ в зависимости от их препаративной формы и расположения устьиц.

Исследование выполнено при финансовой поддержке гранта РФФИ №18-016-00184 «А» и Госзадания №0834-2019-0003. 